23

\title{
MIGRANT SMUGGLING AND THE SOCIAL ORGANISATION OF CROSS-BORDER MOBILITY
}

\author{
Luca Raineri
}

\section{Introducing migrant smuggling: inaccurate framings, wrong approaches, self-fulfilling prophecies}

Although the phenomenon of migrant smuggling has a long history (Wokeck, 1999), the lack of conceptual clarity and methodological rigour have long inhibited the emergence of a scientific field of inquiry on the subject. Since its inception, the criminological perspective has remained dominant (Van Liempt and Sersli, 2012). The theoretical assumptions and normative concerns of law enforcement have shaped the conceptualisations of, and responses to, migrant smuggling. The tendency to look at migrant smuggling more as a pathology than as a social phenomenon has thus long influenced the foundational research questions - and answers - of migrant smuggling research, including about the identities of smugglers and smuggled individuals, their modes of organisation, the drivers of their actions, and the most appropriate policy responses.

This chapter engages in a brief reconstruction of this genealogy. It contrasts early conceptualisations and related popular beliefs on migrant smuggling with recent approaches and findings, which offer a more nuanced and complex view of the phenomenon. It argues that the growing availability of rigorous and empirically-rich studies has contributed to questioning the analytical purchase of institutionalist and neo-institutionalist perspectives on migrant smuggling and crime (Kleemans, 2014), highlighting instead the explanatory value of the network theory, with its emphasis on social capital and ties. Policy approaches built on unconfirmed assumptions may have contributed to rehabilitating past views, making the criminalisation of migrant smuggling a self-fulfilling prophecy.

The predominance of law enforcement concerns and criminological lenses in the apprehension of migrant smuggling transpires from the early studies on the phenomenon commissioned by international organisations (IOM, 1994; UNODC, 2011a) to the more recent iterations of a so-called "crisis" of migrant smuggling and irregular migration in Europe (EUROPOL, 2016). Seminal studies have struggled to disentangle migrant smuggling and its distinctive features from other forms of irregular migration, including most notably human trafficking (ILO, 1975; Salt, 2000; Kyle and Koslowski, 2001; Tailby, 2001). The adoption of the Protocol against the Smuggling of Migrants by Land, Sea and Air - commonly referred to as the Smuggling of Migrants Protocol - supplementing the 2000 UN Convention against 
Transnational Organized Crime (UNCTOC), has supplied an authoritative and clear-cut definition of migrant smuggling, enabling the comparative analysis of a phenomenon that by its very nature straddles national borders. It has also contributed, however, to framing, from the outset, migrant smuggling as a matter of law enforcement, associated with transnational organised crime.

As a result, policy and scholarly discourses on migrant smuggling have an in-built tendency to reiterate the analytical grids and normative standpoint of criminological perspectives. This stands out clearly in at least two domains, which the chapter investigates critically: the economic analogy of migrant smuggling's drivers and modes of organisation; and the security emphasis of response strategies.

Migrant smuggling is often framed as an economic activity (a "business," "market," or "industry") where the lack of legal protection enables smugglers to resort to exploitative and predatory practices (Salt and Stein, 1997; Aronowitz, 2001; Schloenhardt, 2002). This stands in contrast with the posited passivity and victimhood of migrants. The neoliberal analogy between transnational smuggling networks and transnational corporations operating in the legal economy has reinforced the understanding that migrant smuggling is carried out by centralised organisations exercising a hierarchical command and control over a variety of profit-making criminal activities, including the trafficking of women, weapons and drugs. Studies informed by this intellectual scaffolding often strive to obtain accurate figures of the cash flows of the criminal organisations allegedly implicated in migrant smuggling, with a view to dissecting their "business model" (Salt and Stein, 1997; UNODC, 2011a; Reitano and Tinti, 2015). This endeavour somehow reproduces the ambition to attach "memorable numbers" to the estimated profits of criminal organisations, so as to catalyse media attention and political action (Andreas, 2010). Engaging in this direction, a comprehensive retrospective report by UNODC (2011a) cited - without much distancing - the figures of migrant smuggling's estimated profits put forward by early scholarship (all of them reported in Salt and Stein, 1997), ranging from $\$ 3$ billion along the China - US route, to a global annual income of \$5-7 billion. Were this economic power converted into political influence and military might, the standard argument goes, criminal organisations emboldened by smuggling profits, including those of migration, could pose an unprecedented challenge to international stability (Naim, 2012).

The sensation of the imminence of a threat has thus contributed to justifying the mobilisation of considerable resources to stem irregular migration and smuggling. With organised crime depicted as the new Evil Empire, the post-Cold war transition from a warfare to a crimefare posture by Western countries (for the US: see Andreas and Price, 2001; for the EU: see Stambol, 2019) has paved the way to the militarisation of the response to migrant smuggling. Illustrations of this are not in short supply, whether at the US-Mexico border (NuñezNeto, Siskin and Viña, 2005), in Australia (Schloenhardt, 2003; Weber and Grewcock, 2011), or in the EU (Lutterbeck, 2006; Akkerman, 2017). Fuelling the oft-noticed securitisation of migration and smuggling (Buzan, 1991; Galemba, 2018), declarations of a war against migrant smuggling (Raineri and Strazzari, 2021) have been accompanied by the deployment of the arsenal previously tested on the war on drugs (Horwood, 2019), with its focus on enhanced border controls, law enforcement cooperation, and supply eradication.

In the last years, however, the proliferation of critical perspectives, scientific research designs and empirically-rich studies on migrant smuggling increasingly has questioned the underlying assumptions of the criminological approach, leading to the conclusion that the alleged link between migrant smuggling and organised criminal syndicates is poorly substantiated. The subsequent sections of the chapter build on these research developments to show that the prevailing mode of organisation of irregular cross-border mobility is characterised less by 
hierarchical top-down arrangements, than by loose horizontal networks, in which criminal syndicates typically play a marginal role. This leads us to interrogate the conditions that enable the coordination of migrants and smugglers, in the absence of an over-arching regulation and enforcement: mitigating the behaviouralist over-emphasis on profit-maximisation, the network theory highlights that social capital, social ties and social embeddedness help explain the trajectories and choices of the actors involved in migrant smuggling. In this framework, law enforcement measures and securitised approaches appear more effective in reshaping than in disrupting migrant smuggling: by severing cross-border social networks, they paradoxically incentivise the provision of protection by criminal organisations. This observation has led scholars to argue that the criminalisation of migrant smuggling may be seen as a iatrongenic effect of misguided militarised responses.

\section{Emerging evidence on migrant smuggling worldwide: from centralised syndicates to horizontal networks}

Focusing on a variety of geographic areas and investigating different smuggling networks, an increasing amount of literature is putting forward the idea that the organisation of migrant smuggling is, in the largest majority of the cases, less akin to a top-down hierarchical pyramid than to a horizontal network characterised by loose and opportunistic affiliations. Rather than orchestrated by a criminal mastermind pulling the strings behind the scenes, as (neo-) institutionalist criminological approaches would have it, migrant smuggling appears to be the result of the complex interactions of large numbers of smaller, flexible actors efficient at organising piecemeal and ad hoc activities while retaining a relative degree of independence and proactiveness (Baird and Van Liempt, 2016). Within this context, solidarity and trust emerge as key features of the relationship between smugglers and smuggled migrants much more often than previously imagined. An overview of the recent findings of migrant smuggling research across the world contributes to corroborating this view.

Migrant smuggling from China to the US has been associated regularly with organised crime and the traditional triad societies (Robertson, 1977). In recent years, however, the growing availability of fine-grained, multi-sited ethnography has enabled a much more granular understanding, suggesting that migrant smuggling from China to the US is largely dominated by small groups of freelance entrepreneurs who build their own networks independently, often on the basis of their previous social interactions. This has prompted the conclusion that Chinese migrant smuggling organisations "are made up of decentralized associations of criminals of diverse backgrounds, and the relationships among core members are mostly horizontal" (Zhang and Chin, 2002, p. 759), with no single organization monopolising or centralising the sector (Chin, 1999; Zhang, 2008; Zhang and Chin, 2003).

Studies looking at the smuggling of migrants into the US from the Mexican border has led to very similar conclusions. Spener (2009) has noted that local smugglers are poorly organised, with no evidence of market monopolisation by a single group. Sanchez reiterates the same observation, arguing that there is no evidence of "the existence of a single, centralised, power providing operational or logistical support in any of the smuggling groups identified" (Sanchez, 2015, p. 44). Izcara Palacios (2014) has highlighted that the resort to violence is infrequent among competing smuggling groups. This may be seen as the result of kinship ties and links of reciprocity shaping the migrant smuggling "market" (Sanchez, 2017).

The research findings about the organisation of migrant smuggling to the EU are consistent with this picture. Examining the role of Chinese organisations in the smuggling of migrants via the Netherlands, Soudijn (2006) and Kleemans (2007; see also Soudijn and Kleemans, 2009) 
have found no evidence of a centralised organisation, and argue that a plurality of actors coexist, while competition among them is regulated less by the resort to violence than by reputationbuilding measures. Looking at Belgium, Kaizen and Nonneman (2007) have recognised the importance of kinship and ethnic ties in the articulation of migrant smuggling, arguing that smugglers operate in small groups characterised by cellular structures and opportunistic business partnerships. In Poland, Okolski (2000) has noted that migrant smuggling operations exhibit limited engagement by the Russian mafia.

Studies focusing on migrant smuggling across the Middle East, and especially Turkey, have led to similar observations. Demir, Sever and Kahya (2017) note the absence of an "international umbrella organization" with "branches in several countries," arguing instead that migrant smuggling is based on "loosely connected" groups with limited if any internal hierarchy, that "communicate and cooperate [...] horizontally" across the different stages of the process (Demir Sever and Kahya, 2017, pp. 384-385; see also Campana, 2020). Case studies focusing on Turkey-based organisations smuggling migrants from Syria (Achilli, 2018), Iran and Iraq (Içduygu and Toktas, 2002; Içduygu, 2018) corroborate the same findings, noting that smugglers operate independently along a small part of a larger chain with no centralised organisation or oversight.

Studies focusing on Africa, too, have further confirmed the emerging general conclusion that small-scale coordination on a case-by-case basis, rather than central oversight by hierarchical criminal syndicates, is the prevalent mode of organisation of transnational migrant smuggling. In Libya, this was the case during the Gaddafi regime (Pastore, Monzini and Sciortino, 2006). Interestingly, the fall of the authoritarian ruler and the rise of a patchwork of armed groups and militias does not appear to have changed the picture radically (Campana, 2018; Sanchez, 2020). "The presence of kingpins who can exert monopolistic control over a certain route," while frequently aired in media and policy discourses, remains strongly disputed and poorly corroborated by convincing evidence (Campana, 2018, p. 493). In a similar vein, researches on West Africa have noted that in this region, too, migrant smuggling is fragmented, and depends more on individual initiatives, 'homespun' organisational arrangements, and smallscale negotiations than on an integrated chain of professional services deployed internationally and centralised vertically (UNODC, 2011b; Benattia, Armitano and Robinson, 2015). In Niger, where migratory flows directed to Libya and Europe have soared considerably since 2014, smuggling remains dominated by "small-scale low-investment activities" featuring "rather fragmented and uncoordinated chains of actors" (Brachet, 2018, p. 29), while the dynamics of market competition - essentially non-violent in nature - witness to the absence of a consolidated criminal monopoly (Raineri, 2018).

The migratory route from the Horn of Africa may represent a possible exception to this trend. Here, studies commissioned or carried out by think tanks, international organisations and law enforcement agencies contend that hierarchically structured criminal cartels are able to coordinate the shipping of migrants from Eritrea to Europe via Libya (Sahan/IGAD, 2016; UNHCR, 2019). Recent scholarly work, however, has questioned this view. Emerging evidence from ethnographic immersion (Ayalew Mengiste, 2018) and social network analysis (Campana, 2018) suggests that the modus operandi of migrant smuggling from the Horn of Africa to Europe remains highly fragmented. The resort to sophisticated organisational arrangements, which has also been noted, coexists with a high degree of social embeddedness and permeability of smuggling networks operating along this route.

One could be tempted to argue that the over-reliance on bottom-up research designs may have contributed to distorting these findings. After all, ethnographic methods generally provide access to the perceptions of smuggled migrants and low-level smugglers who, even if 
well-intentioned and transparent, may be simply unaware of the functioning of the higher, more secretive echelons of the organisations that empower and shape their activities (a similar position surfaces, for instance, in Malakooti, 2016). The reality seems to be exactly the opposite though. Data access limitations have concurred to cement the hegemony of the criminological approach to the study of migrant smuggling. As a result of the difficulties in observing, measuring, and gathering reliable data on an inherently opaque activity (Koser, 2009; McAuliffe and Laczko, 2016), studies on migrant smuggling have long been shaped by law enforcement who (claim to) have first-hand information, as UNODC has also recognized (UNODC, 2011a). Ethnographic research on migrant smuggling has contributed to eroding this informational bias. Interestingly, subsequent studies drawing on alternative, non-ethnographic methods of data collection and analysis - such as judicial sources, regression analysis of wiretapping metadata, content analysis of wiretapping records and social network analysis (SNA) - have corroborated the same conclusions (Soudijn and Kleemans, 2009; Webb and Burrows, 2009; Leman and Janssens, 2011; Demir, Sever and Kahya, 2017; Campana, 2018). This proliferation points to an emerging consensus that the involvement of hierarchically structured criminal syndicates in the organisation of migrant smuggling is tenuous at best.

Scholars have put forward a plausible explanation of this seeming anomaly. Arguably, traditional criminal organisations excel at those racketeering activities in which territorial control can be exploited, such as gambling, prostitution and protection (Paoli, 2003). Being geographically constrained in their own turf, however, they are ill-equipped to meet the fluid demands of a multi-sited, transnational market, such as migrant smuggling. This is what Zhang and Chin $(2002,2003)$ call the structural deficiency of traditional criminal cartels. Nevertheless, as the subsequent sections suggest, law enforcement measures to curtail (the supply side of) human smuggling can incentivise the demand for the protection of informal transactions, thereby creating a fertile ground for organised criminal groups to step back in.

\section{Migrant smuggling and network theory}

Building on the above, it is safe to conclude that research findings do not uphold the narrative of migrant smuggling as organised by tentacular crime syndicates structured hierarchically and able to generate (criminal) economies of scale by ensuring central oversight to the transnational shipping of migrants from their home village to their countries of destination. To the contrary, migrant smuggling is typically facilitated by networks organised horizontally, featuring multiple affiliations and limited geographic reach. Migrants typically negotiate their shipment through every single leg of their journey with a variety of different providers of smuggling services, who generally act as freelance entrepreneurs and do not report to a higher-level hierarchy belonging to a single, unitary, criminal organisation. This is not to imply that all social organisation and hierarchy is entirely absent from migrant smuggling. Proponents of the network theory acknowledge that smugglers do retain different levels of influence, but this is more the result of their capacity to connect a variety of networks and bridge a diversity of social environments than of any pre-given organisational hierarchy (Kleemans, 2007; Campana, 2018). In other words, it is less a matter of top-down dominance from a vertical perspective, than of central strategic positioning from a horizontal perspective.

Within this framework, the network theory opens up the questions of how migrants and smugglers establish connections, and negotiate their agreements. On the one hand, in fact, the availability of a plurality of providers of smuggling opportunities, rather than of a single violent monopolist, enables migrants to exercise a much greater degree of autonomy and agency (Van Liempt and Doomernik, 2006; Sanchez, 2020). It becomes apparent that in many cases migrants 
choose their own smugglers, building on the feedback collected from common acquaintances or online (Campana, 2020). While the exploitation of naivety and need make scams far from infrequent, increasing access to social media technology contributes to reducing informational asymmetry. On the other hand, trust between migrants and smugglers is of extreme importance (Kleemans, 2007; Golovko, 2018; Sanchez, 2018). This is in line with the findings of an emerging ethnographic literature on criminal networks in general (Nordstrom, 2007), and contributes to questioning the standard assumption held by an influential tradition of political science - from Hobbes to Weber - arguing that transactions taking place beyond state regulation are bound to generate anarchy, violence and ultimately social disintegration. The observation, often reported, that migrants typically trust smugglers more than the law enforcement apparatuses tasked with fighting them (see for instance Golovko, 2018) highlights that this may not be always the case. In other words, the network theory shifts the focus away from the overemphasis on economic capital - whether that spent by migrants or raised by profit-seeking criminal organisations - to the social capital as a key variable to explain the trajectories, dynamics and organisation of migrant smuggling.

From this perspective, pre-existing bonds between smugglers and migrants often provide an asset to leverage social capital and minimise uncertainty and risk. The literature offers ample illustration of how family networks account for a key enabler of migration, including irregular migration and smuggling (Staring, 2004; Bilger, Hofmann and Jandl, 2006; Zhang, 2008). Increasingly, available scholarship has highlighted that migrant smugglers frequently share the same social and ethnic background as the migrants being smuggled (Neske, 2006; Soudijn, 2006; Majidi, 2018; Stone-Cadena and Álvarez Velasco 2018). Coming from impoverished communities, smugglers choose their "career" less out of greed than lack of alternatives, with migrant smuggling often complementing other sources of income (Sanchez, 2020). As a result, smugglers often share the same milieu and concerns as the migrants, leading to a blurring of the lines between the two categories.

The focus on the motivations and the recognition of the common social and moral standpoint that often ties smugglers and migrants together has also helped debunk the myth of a normative polarisation between, respectively, ruthless predators and naive victims. To be sure, abuses and scams are not uncommon in migrant smuggling, but their exhibition and media overemphasis - often with sensationalistic tones - has all too often led us to overlook the positive interactions that are frequent between migrants and smugglers. There is no shortage of reports highlighting the "morality" of smugglers, who can come to be seen as "saviours" by migrants left with few alternatives (Pastore, Monzini and Sciortino, 2006; Van Liempt, 2007; Tinti and Reitano, 2016; Achilli, 2018; Ayalew Mengiste, 2018). At the same time, smugglers often see themselves as honest providers of a service that meets an exogenously given social demand of mobility, which is constrained by legislations widely held as unjust and unfair (Golovko, 2018; Mannocchi, 2019). Altruistic motivations often compound profit-seeking, making the interactions between smugglers and migrants irreducible to an economic rationality calculus. As Sanchez (2020, p. 22) has observed, "[smuggling] fees are often dependent of negotiations, community obligations, moral duty and other forms of reciprocity that go beyond financial values or returns, and are hardly ever the same, even for migrants traveling together or following the same trajectory."

These observations highlight that the research on migrant smuggling is in line with the overall conceptualisation of the 'criminal' world that is emerging from recent studies; i.e., that crime is not separate from, but deeply interwoven into the texture of ordinary social life and entangled in everyday intercourses, where criminal contacts intermesh with habitual social patterns (Kleemans and Van de Bunt, 1999; Hudson, 2014; Baird and Van Liempt, 2016). In 
the same vein, smugglers are in most cases more accurately described as ordinary citizens partially engaging in extralegal activities, than as professional gangsters segregated in a secretive criminal underworld.

\section{Anti-smuggling policies: the iatrogenic effects of disrupting networks}

The concept of "criminal iatrogenesis" was introduced to describe cases in which anti-criminal policies ended up fuelling, rather than curbing, criminal activities and organisations, prompting the observation that the cure prescribed to fight crime proved worse than the disease (Cohen, 1988; see also Brenner, 2021, in this volume). In its early iterations, criminal iatrogenesis referred mostly to the 'unintended consequences' or 'collateral damage' produced by the US "war on drugs." The questionable results of the latter have not prevented the revamping of some of its measures in the framework of an emerging war on migrant smuggling (Horwood, 2019), including an almost exclusive focus on (the curtailment of) the supply side of smuggling activities. Concurring with this view, scholars have highlighted the iatrogenic effects of the policies designed to fight migrant smuggling in Australia (Weber and Grewcock, 2011) and Europe (Stambol, 2019), spilling over to, respectively, south-east Asia and Africa.

Across a multiplicity of different country cases, in fact, common features emerge from the analysis of the strategies, policies and measures adopted to respond to, and fight against, migrant smuggling. These typically include: a restriction of the visa regime for unregulated border crossing; a criminalisation of migrant smuggling, including the adoption of harsh penalties for smuggling-related offences; enhanced border protection, often with the use of military assets; the externalisation of border controls to countries of origin and transit of migratory flows, including the creation of buffer zones; the use of transit camps and off-shore processing; the declaration of a war against migrant smuggling and trafficking (often conflated), framed as part of a broader fight against terrorism and transnational organised crime; and the strengthening of law enforcement cooperation with countries of transit and origin of migrants (Weber and Grewcock, 2011).

The extent to which these measures have proved successful in curbing migrant smuggling worldwide remains highly questionable. At the same time, evidence from different regions is piling up to suggest that such anti-smuggling policies have often resulted in the organisational restructuring of migrant smuggling, prompting a progressive replacement of small-scale, 'homespun' networks with larger, more sophisticated criminal organisations (UNODC 2011a, 2018). The latter are in fact better equipped for circumventing stricter border controls and forging the high-level partnerships required to condone illicit activities, owing to their greater economic resources and skilful use of organised violence. The rising entry barrier in the illegal(-ised) market of migrant smuggling is therefore credited for pushing towards greater criminal professionalisation while at the same time driving smaller operators out of the market. Furthermore, the disruption of small-scale migrant smuggling networks that is prompted by anti-smuggling law enforcement measures contributes to severing the "chain of trust" and personalised ties that make the infrastructure of cross-border mobility (Van Liempt, 2007). This can fuel a demand for the protection and enforcement (armed, if need be) of risky but profitable extralegal transactions, which mafia-like organisations present in the territory may be eager to meet with a view to expanding their protection rackets. Key brokers of transnational smuggling networks are thus absorbed, more or less willingly, within organised criminal structures consolidating beyond borders and confined localities (Morselli, 2009).

There is no shortage of reports documenting these dynamics. The rising stakes of wellstructured criminal and armed groups in the organisation and protection of migrant smuggling 
has been noted in a variety of contexts, including the Caribbean (Kyle and Scarcelli, 2009), Libya (Stocker, 2017; Campana, 2018), and Sudan (Tubiana, Warin and Saeneen 2018), to name but a few. As this phenomenon appears correlated to the strengthening of transnational law enforcement efforts against migrant smuggling, critical observers have argued that antismuggling policies have counterintuitively contributed to "manufacturing smugglers" (Brachet, 2018).

These observations, however, should not lead one to overlook the important analytical distinction between smuggling and protection providers. Drawing on the ideal-types introduced by Tilly's (1985) historical sociology, smugglers refer to the actors that facilitate the cross-border clandestine shipment of people and goods to make profit. Protection providers, instead, are seldom involved in the actual delivery of smuggling services, and limit themselves to controlling the territory where migrant smuggling takes place. In exchange, they extract (or extort) a cut of the revenues from smugglers operating in 'their' territory - which may be substantial, as Sanchez (2020) suggests. The relationships between smugglers and criminal organisations engaged in the protection of criminal activities can range from cooperation to rivalry. Smugglers can benefit from the weak territorial control that criminal organisations contribute to, but they can also resent a situation of unpredictability and unwanted attention. In some cases, "organised crime groups involved in protection might recruit former smugglers to help them levy the protection tax because of their knowledge of the routes, and their ability to detect other smugglers" (Campana, 2020). In other cases, criminal protectors can coerce smugglers into partnerships through extortion, for instance, by kidnapping migrants in transit and asking a ransom to the smugglers for their liberation, as observed in Libya, Mali and Mexico (Spener, 2009; Izcara Palacios, 2014; Malakooti, 2019).

The entrance of armed criminal organisations into the migrant smuggling "business" frequently leads to an escalation of exploitation and abusive practices vis-à-vis migrants. Numerous reports by UN agencies and NGOs provide ample illustration of this (UNSMIL and OHCHR, 2016; Testa, 2019; UNHCR, 2019). The borders between migrant smuggling and trafficking are thus subject to erosion (Reitano et al. 2018). On the one hand, this further highlights the iatrogenesis of policies that are often designed, at least on paper, to serve humanitarian purposes such as "saving lives": this was, for instance, the stated priority number one of the EU Agenda on Migration issued in the aftermath of the shipwreck off the shore of the island of Lampedusa that killed more than 800 people. On the other hand, there is a surprising - and somewhat disturbing - lack of evidence that safety and risk concerns, even if backed by reliable information, significantly can influence the preferences of migrants and prospective migrants resorting to smuggling. Recent reports (Raineri and Golovko, 2019) note that migrants often leave their countries of origin in spite of being reportedly aware of the risks that await them on the road, suggesting that, with the disruption of smuggling networks and "chains of trust," accessibility, affordability and (poor) law enforcement have become the key determinants of irregular migration's routes, modalities and destinations.

\section{Conclusion}

The criminalisation of migrant smuggling may be seen as a self-fulfilling prophecy. The concept of migrant smuggling was immediately incorporated in the semantic field of organised crime when it was originally disentangled from the cognate notions of human trafficking and irregular migration. The growing availability of scholarly works and empirically-informed studies, however, has contributed to dispelling the early image of migrant smuggling as organised by tentacular crime syndicates structured vertically and stretched transnationally. A different theory 
has progressively made its way, one that investigates migrant smuggling by stressing the significance of ad-hoc partnerships over rigid affiliations, of social capital over economic capital, of agency over coercion, of social embeddedness over seclusion, of normality over exceptionality, and most importantly, of horizontal networks over top-down hierarchies.

However, the transnational diffusion of measures to combat migrant smuggling has contributed to prompting a transformation of the phenomenon. By disrupting of the "chain of trust" that typically provides the infrastructure of migrant smuggling, unscrupulous law enforcement measures have in many cases paved the way to the entrance of criminal syndicates in a sector where they used to be marginal. The iatrogenic effect of anti-smuggling policies thus turns the arrow of causality between "threat" and response on its head, making organised crime infiltration less the cause of anti-smuggling law enforcement measures, than the consequence. This should not lead one to underwrite the conflation of migrant smuggling and organised crime, that media and policy discourses tend to depict. Criminal and armed cartels are only infrequently involved in the actual organisation of migrants' cross-border journeys. More often, they prey on smugglers and migrants alike by upholding a protection racket of migrant smuggling unfolding in 'their' territories.

For all these reasons, it seems fair to conclude that - in the field of migration - the very notion of "smuggler" is problematic and calls for some degree of critical distancing. Its connotation has become too politically charged to claim a degree of neutrality suitable for scientific investigation. At the same time, its denotation runs the risk of being empirically empty. Ethnographic research has demonstrated that one can hardly encounter "smugglers" on the ground, as both migrants and the facilitators of migrant smuggling use a variety of different concepts, such as "passeurs" in francophone West Africa (Brachet, 2018), "connection men" in anglophone Africa (Lucht, 2012), "snakeheads" in China (Chin, 1999; Zhang, 2008), "coyotes" in Latin America (Spener, 2009; Stone-Cadena and Álvarez Velasco, 2018), as well as other terms depending on the context. This proliferation points to a research agenda that, aware of its own positioning in a field of struggle, avoids oversimplifying the reality with conceptual shortcuts that are potentially misleading, and engages instead in a careful, detailed, fine-grained mapping of a social phenomenon characterised by a huge degree of variation that it would be unscrupulous to gloss over.

\section{References}

Achilli, L. (2018) 'The 'Good' Smuggler: The Ethics and Morals of Human Smuggling among Syrians'. Annals of the American Academy of Political and Social Sciences 676(1), pp. 63-77.

Akkerman, M. (2017) 'Militarization of European Border Security' in Karampekios, N., Oikonomou, I. and Carayannis, E. (eds.) The Emergence of EU Defense Research Policy. From Innovation to Militarization. Berlin: Springer, pp. 337-355.

Andreas, P. (2010) 'The Politics of Measuring Illicit Flows and Policy Effectiveness' in Andreas, P. and Greenhill, K. (eds.) Sex, Drugs, and Body Counts, The Politics of Numbers in Global Crime and Conflict. Ithaca: Cornell University Press, pp. 23-45.

Andreas, P. and Price, R. (2001) 'From War Fighting to Crime Fighting: Transforming the American National Security State'. International Studies Review 3(3), pp. 31-52.

Aronowitz, A. (2001) 'Smuggling and Trafficking in Human Beings: The Phenomenon, the Markets That Drive It and the Organizations That Promote It'. European Journal on Criminal Policy and Research 9(2), pp. 163-195.

Ayalew Mengiste, T. (2018) 'Refugee Protections from Below: Smuggling in the Eritrea-Ethiopia Context'. Annals of the American Academy of Political and Social Sciences 676(1), pp. 57-76.

Baird, T. and Van Liempt, I. (2016) 'Scrutinising the Double Disadvantage: Knowledge Production in the Messy Field of Migrant Smuggling'. Journal of Ethnic and Migration Studies 42(3), pp. 400-417. 
Benattia, T., Armitano, F. and Robinson, H. (2015) Irregular Migration between West Africa, North Africa and the Mediterranean. Abuja-Paris: Altai Consulting.

Bilger, V., Hofmann, M. and Jandl, M. (2006) 'Human Smuggling as a Transnational Service Industry: Evidence From Austria. International Migration 44(4), pp. 59-92.

Brachet, J. (2018) 'Manufacturing Smugglers: From Irregular to Clandestine Mobility in Sahara'. Annals of the American Academy of Political and Social Science 676(1), pp. 16-35.

Buzan, B. (1991) People, States and Fear. An Agenda for International Security Studies in the Post-Cold War Era. London: Rowman and Littlefield.

Campana, P. (2018) 'Out of Africa: The Organisation of Migrant Smuggling across the Mediterranean'. European Journal of Criminology 15(4), pp. 481-502.

Campana, P. (2020) 'Human Smuggling: Structure and Mechanisms'. Crime and Justice 49(1), DOI: 10.1 $086 / 708663$

Chin, K. (1999) Smuggled Chinese: Clandestine Immigration to the United States. Philadelphia: Temple University Press.

Cohen, S. (1988) 'Western Crime Models in the Third World: Benign or Malignant' in Cohen, S. (ed.) Against Criminology. New Brunswick: Transaction Publisher, pp. 172-202.

Demir, O., Sever, M. and Kahya, Y. (2017) 'The Social Organisation of Migrant Smugglers in Turkey: Roles and Functions'. European Journal of Criminal Policy Research 23(3), pp. 371-391.

EUROPOL (2016) Migrant Smuggling in the EU. The Hague: EUROPOL.

Galemba, R. (2018) "He Used to be a Pollero' The Securitisation of Migration and the Smuggler/migrant Nexus at the Mexico-Guatemala Border'. Journal of Ethnic and Migration Studies 44(5), pp. 870-886.

Golovko, E. (2018) Players of Many Parts: The Evolving Role of Smugglers in West Africa's Migration Economy. Geneva: Mixed Migration Centre. Available at: https://mixedmigration.org/resource/players-ofmany-parts/

Horwood, C. (2019) The New 'Public Enemy Number One'. Comparing and Contrasting the War on Drugs and the Emerging War on Migrant Smugglers. Geneva: Mixed Migration Centre. Available at: https:// mixedmigration.org/wp-content/uploads/2019/03/060_new-public-enemy-number-1_fullreport.pdf

Hudson, R. (2014) 'Thinking through the Relationships between Legal and Illegal Activities and Economies: Spaces, Flows and Pathways'. Journal of Economic Geography 14(4), pp. 775-795.

İçduygu, A. (2018) 'Middle East' in Triandafyllidou, A. and McAuliffe, M. (eds.) Migrant Smuggling Data and Research: A Global Review of the Emerging Evidence Base. Geneva: IOM, pp. 19-44.

İçduygu, A. and Toktas, S. (2002) 'How Do Smuggling and Trafficking Operate via Irregular Border Crossings in the Middle East? Evidence from Fieldwork in Turkey'. International Migration 40(6), pp. $25-54$.

ILO (1975) Migrant Workers (Supplementary Provisions) Convention (No. 143). Geneva: ILO.

IOM (1994) 'Trafficking in Migrants: Characteristics and Trends in Different Regions of the World'. Discussion Paper No. 1/11th IOM Seminar on Migration. Geneva: IOM.

Izcara Palacios, S. (2014) 'Coyotaje and Drugs: Two Different Businesses'. Bulletin of Latin American Research 34(3), pp. 324-339.

Kaizen, J. and Nonneman, W. (2007) 'Irregular Migration in Belgium and Organized Crime: An Overview'. International Migration 45(2), pp. 121-146.

Kleemans, E. (2007) 'Organized Crime, Transit Crime, and Racketeering'. Crime and Justice 35(1), pp. 163-215.

Kleemans, E. (2014) 'Theoretical Perspectives on Organized Crime' in Paoli, L. (ed.) Oxford Handbook of Organised Crime. Oxford: Oxford University Press, DOI: 10.1093/oxfordhb/9780199730445.013.005

Kleemans, E. and Van de Bunt, H. (1999) 'The Social Embeddedness of Organized Crime'. Transnational Organized Crime 5(2), pp. 19-36.

Koser, K. (2009) 'Dimensions and Dynamics of Irregular Migration'. Population, Space and Place 16(3), pp. 181-193.

Kyle, D. and Koslowski, R. (eds.) (2001) Global Human Smuggling. Comparative Perspectives. Baltimore: Johns Hopkins University Press.

Kyle, D. and Scarcelli, M. (2009) 'Migrant Smuggling and the Violence Question: Evolving Illicit Migration Markets for Cuban and Haitian Refugees'. Crime Law and Social Change 52(3), pp. 297-311.

Leman, J. and Janssens, S. (2011) 'Albanian Entrepreneurial Practices in Human Smuggling and Trafficking: On the Road to the United Kingdom via Brussels, 1995-2005'. International Migration 50(6), pp. 166-179. 


\section{Migrant smuggling}

Lucht, H. (2012) Darkness before Daybreak. African Migrants Living on the Margins in Southern Italy Today. Berkeley: University of California Press.

Lutterbeck, D. (2006) 'Policing Migration in the Mediterranean'. Mediterranean Politics 11(1), pp. 59-82.

Majidi, N. (2018) 'Community Dimensions of Smuggling: The Case of Afghanistan and Somalia'. Annals of the American Academy of Political and Social Sciences 676(1), pp. 97-113.

Malakooti, A. (2016) 'North Africa' in McAuliffe, M. and Laczko, F. (eds.) Migrant Smuggling Data and Research: A Global Review of the Emerging Evidence Base. Geneva: IOM, pp. 85-104.

Malakooti, A. (2019) The Political Economy of Migrant Detention in Libya: Understanding the Players and the Business Models. Geneva: Global Initiative Against Transnational Organized Crime. Available at: https://globalinitiative.net/analysis/migrant-detention-libya/

Mannocchi, F. (2019) Io, Khaled, vendo uomini e sono innocente. Torino: Einaudi.

McAuliffe, M. and Laczko, F. (eds.) (2016) Migrant Smuggling Data and Research: A Global Review of the Emerging Evidence Base. Geneva: IOM.

Morselli, C. (2009) Inside Criminal Networks. New York: Springer.

Naim, M. (2012) 'Mafia States, Organized Crime Takes Office'. Foreign Affairs 91(3), pp. 100-111.

Neske, M. (2006) 'Human Smuggling to and through Germany'. International Migration 44(4), pp. 121-163.

Nordstrom, C. (2007) Global Outlaws: Crime, Money and Power in the Contemporary World. Berkeley: University of California Press.

Nuñez-Neto, B., Siskin, A. and Viña, S. (2005) Border Security: Apprehensions of 'Other than Mexican' aliens. Washington, DC: Congressional Research Service Report for Congress. Available at: https:// trac.syr.edu/immigration/library/P1.pdf

Okolski, M. (2000) 'Illegality of International Population Movements in Poland', International Migration $38(3)$, pp. $57-89$.

Paoli, L. (2003) Mafia Brotherhoods: Organized Crime, Italian Style. Oxford: Oxford University Press.

Pastore, F., Monzini, P. and Sciortino, G. (2006) 'Schengen's Soft Underbelly? Irregular Migration and Human Smuggling Across Land and Sea Borders to Italy'. International Migration 44(4), pp. 95-119.

Raineri, L (2018) 'Human Smuggling across Niger: State-sponsored Protection Rackets and Contradictory Security Imperatives', Journal of Modern African Studies 56(1), pp. 63-86.

Raineri, L. and Golovko, E. (2019) Navigating Borderlands in the Sahel. Border Security Governance and Mixed Migration in Liptako-Gourma. Geneva: Mixed Migration Centre. Available at: https://mixedmigration.org/ resource/navigating-borderlands-in-the-sahel/

Raineri, L., and Strazzari, F., 2021. Dissecting the EU Response to the 'Migration Crisis', in MacGinty, R. (ed.) Title TBC. Manchester: Manchester University Press.

Reitano, T. and Tinti, P. (2015) 'Survive and Advance. The Economics of Smuggling Refugees and Migrants into Europe', ISS Paper 289. Dakar: Institute for Security Studies. Available at: https:// issafrica.org/research/papers/survive-and-advance-the-economics-of-smuggling-refugees-and-migrantsinto-europe

Reitano, T., McCormack, S., Micallef, M. and Shaw, M. (2018) Responding to the Human Trafficking-migrant Smuggling Nexus. Geneva: The Global Initiative Against Transnational Organized Crime. Available at: https://globalinitiative.net/wp-content/uploads/2018/07/Reitano-McCormack-Trafficking-SmugglingNexus-in-Libya-July-2018.pdf

Robertson, F. (1977) Triangle of Death: The Inside Story of the Triads, the Chinese Mafia. London: Routledge.

Sahan/IGAD (2016) Human Trafficking and Smuggling on the Horn of Africa-Central Mediterranean Route. Nairobi: IGAD. Available at: https://igad.int/attachments/1284_ISSP\%20Sahan\%20HST\%20Report $\% 20 \% 2018$ ii2016\%20FINAL\%20FINAL.pdf

Salt, J. (2000) 'Trafficking and Human Smuggling: A European Perspective'. International Migration 38(3), pp. 31-56.

Salt, J. and Stein, J. (1997) 'Migration as a Business: The Case of Trafficking'. International Migration 35(4), pp. 467-494.

Sanchez, G. (2015) Human Smuggling and Border Crossing. Abingdon: Routledge

Sanchez, G. (2017) 'Critical Perspectives on Clandestine Migration Facilitation: An Overview of Migrant Smuggling Research'. Journal on Migration and Human Security 5(1), pp. 9-27.

Sanchez, G. (2018) 'Mexico' in Triandafyllidou, A. and McAuliffe, M. (eds.) Migrant Smuggling Data and Research: A Global Review of the Emerging Evidence Base, vol. 2. Geneva: IOM, pp. 143-166. 


\section{Luca Raineri}

Sanchez, G. (2020) 'Beyond Militias and Tribes: The Facilitation of Migration in Libya', EUI Working Paper RSCAS 2020/09. Available at: https://cadmus.eui.eu/bitstream/handle/1814/66186/ RSCAS_2020_09.pdf?sequence $=1$ \&isAllowed=y

Schloenhardt, A. (2002) Organised Crime and Migrant Smuggling: Australia and the Asia-Pacific, Research and Public Policy Series No. 44. Canberra: Australian Institute of Criminology. Available at: https:// www.aic.gov.au/publications/rpp/rpp44

Schloenhardt, A. (2003) Migrant Smuggling: Illegal Migration and Organised Crime in Australia and the Asia Pacific Region. Leiden: Brill.

Soudijn, M. (2006) Chinese Human Smuggling in Transit. Leiden: Netherlands Institute for the Study of Crime and Law Enforcement.

Soudijn, M. and Kleemans, E. (2009) 'Chinese Organized Crime and Situational Context: Comparing Human Smuggling and Synthetic Drugs Trafficking'. Crime, Law and Social Change 52(5), pp. 457-474.

Spener, D. (2009) Clandestine Crossings: Migrants and Coyotes on the Texas-Mexico Border. New York: Cornell University Press.

Stambol, E.M. (2019) 'The Rise of Crimefare Europe: Fighting Migrant Smuggling in West Africa'. European Foreign Affairs Review 24(3), pp. 287-308.

Staring, R. (2004) 'Facilitating the Arrival of Illegal Immigrants in the Netherlands: Irregular Chain Migration Versus Smuggling Chains'. Journal of International Migration and Integration 5(3), pp. $273-294$.

Stocker, V. (2017) Leaving Libya. Rapid Assessment of Municipalities of Departures of Migrants in Libya. Tunis: Altai Consulting. Available at: http://www.altaiconsulting.com/wp-content/uploads/2017/08/2017_AltaiConsulting_Leaving-Libya-Rapid-Assessment-of-Municipalities-of-Departure-of-Migrants-in-Libya.pdf

Stone-Cadena, V. and Álvarez Velasco, S. (2018) 'Historicizing mobility: coyoterismo in the indigenous Ecuadorian migration industry'. Annals of the American Academy of Political and Social Sciences 676(1), pp. 194-211.

Tailby, R. (2001) 'Organised Crime and People Smuggling: Trafficking to Australia'. Trends and Issues in Crime and Criminal Justice 208. Available at: https://www.aic.gov.au/publications/tandi/tandi208

Testa, G. (2019) Waning Welcome: The Growing Challenges Facing Mixed Migration Flows from Venezuela. Geneva: Mixed Migration Centre. Available at: https://mixedmigration.org/resource/waningwelcome-the-growing-challenges-facing-mixed-migration-flows-from-venezuela/

Tilly, C. (1985) 'War Making and State Making as Organized Crime' in Evans, P., Rueschemeyer, D. and Skocpol, T. (eds.) Bringing the State Back In. Cambridge: Cambridge University Press, pp. 169-191.

Tinti, P. and Reitano, T. (2016) Migrant, Refugee, Smuggler, Saviour. New York: Hurst Publisher.

Tubiana, J., Warin, C. and Saeneen, G. (2018) Multilateral Damage. The Impact of EU Migration Policies on Central Saharan Routes. The Hague: Clingendael CRU Report. Available at: https://www.clingendael.org/pub/2 018/multilateral-damage/

UNHCR (2019) From Hand to Hand: The Migratory Experience of Refugees and Migrants from East Africa across Libya. Geneva: UNHCR.

UNODC (2011a) Smuggling of Migrants: A Global Review and Annotated Bibliography of Recent Publications. Vienna: UNODC.

UNODC (2011b) The Role of Organized Crime in the Smuggling of Migrants from West Africa to the European Union. Vienna: UNODC.

UNODC (2018) Global Study on Smuggling of Migrants. Vienna: UNODC.

UNSMIL and OHCHR (2016) Detained and Dehumanized. Report on Human Rights Abuses against Migrants in Libya. Geneva: OHCHR.

Van Liempt, I. (2007) Navigating Borders: Inside Perspectives on the Process of Human Smuggling into the Netherlands. Amsterdam: Amsterdam University Press.

Van Liempt, I. and Doomernik, J. (2006) 'Migrant's Agency in the Smuggling Process: The Perspectives of Smuggled Migrants in the Netherlands'. International Migration 44(4), pp. 165-190.

Van Liempt, I. and Sersli, S. (2012) State Responses and Migrant Experiences with Human Smuggling: A Reality Check. Antipode 45(4), pp. 1029-1046.

Webb, S. and Burrows, J. (2009) 'Organised Immigration Crime: A Post-conviction Study', Research Report 15. London: Home Office. Available at: https://assets.publishing.service.gov.uk/government/ uploads/system/uploads/attachment_data/file/116629/horr15-report.pdf

Weber, L. and Grewcock, M. (2011) 'Criminalizing People Smuggling: Preventing Or Globalizing Harm?’ in Allum, F. and Gilmour, S. (eds.) The Routledge Handbook of Transnational Organized Crime. London: Routledge, pp. 379-390. 


\section{Migrant smuggling}

Wokeck, M. (1999) Trade in Strangers: The Beginnings of Mass Migration to North America. University Park: Pennsylvania State University Press.

Zhang, S. (2008) Chinese Human Smuggling Organizations: Families, Social Networks, and Cultural Imperatives. Stanford: Stanford University Press.

Zhang, S. and Chin, K. (2002) 'Enter the Dragon: Inside Chinese Human Smuggling Organizations'. Criminology 40(4), pp. 737-767.

Zhang, S. and Chin, K. (2003) 'The Declining Significance of Triad Societies in Transnational Illegal Activities: A Structural Deficiency Perspective’. British Journal of Criminology 43(3), pp. 469-488. 